\title{
The other side of Ecology: thinking about the human bias in our ecological analyses for biodiversity conservation
}

Sérgio de Faria Lopes ${ }^{1, *}$

\begin{abstract}
Ecology as a science emerged within a classic Cartesian positivist context, in which relationships should be understood by the division of knowledge and its subsequent generalization. Over-time, ecology has addressed many questions, from the processes that lead to the origin and maintenance of life to modern theories of trophic webs and nonequilibrium. However, the ecological models and ecosystem theories used in the field of ecology have had difficulty integrating man into analysis, although humans have emerged as a global force that is transforming the entirety of planet. In this sense, currently, advances in the field of the ecology that develop outside of research centers is under the spotlight for social, political, economic and environmental goals, mainly due the environmental crisis resulting from overexploitation of natural resources and habitat fragmentation. Herein a brief historical review of ecology as science and humankind's relationship with nature is presented, with the objective of assessing the impartiality and neutrality of scientific research and new possibilities of understanding and consolidating knowledge, specifically local ecological knowledge. Moreover, and in a contemporary way, the human being presence in environmental relationships, both as a study object, as well as an observer, proposer of interpretation routes and discussion, requires new possibilities. Among these proposals, the human bias in studies of the biodiversity conservation emerges as the other side of ecology, integrating scientific knowledge with local ecological knowledge and converging with the idea of complexity in the relationships of humans with the environment.
\end{abstract}

Keywords: Complexity, Evolutionary Ethnobiology, History of Ecology, Local Ecological Knowledge

\footnotetext{
${ }_{1}^{1}$ Departamento de Biologia, Universidade Estadual da Paraíba, Av. Baraúnas n 351, Bodocongó, Campina Grande, Paraíba, 58430-335, Brasil.
}

* $\quad$ E-mail address: defarialopes@gmail.com 


\section{INTRODUCTION}

Ecology, as a science, emerged from deep questions about possible explanations of natural phenomena that have faced mankind since the beginning (Ellis 2015). In the $16^{\text {th }}$ century, one of these great mysteries in need of "scientific" unravelling was simply the distinction of what was alive and was not. Later came questions regarding the complexities of the chemical processes involved with life and role of abiotic factors in driving it. Over time, the questions investigated by ecologist came to address the complex interactions between the environment and living beings (Agrawal et al 2007; Bramwell 1989; Graham and Dayton 2002; McIntosh 1985). However, human involvement was always considered outside of the context of these interactions, in order to be neutral and objective in the discovery and production of knowledge (Prigogine 1994).

Ecology arises, then, from a classic Cartesian positivist context in which relationships are understood by the division of knowledge and its subsequent widespread, without relying on human involvement, especially regarding the consequences of overexploitation of natural resources (Pimm et al. 2014). However, alterations to ecological and evolutionary processes across the Earth have been made by human societies since the beginning (Barnosky 2014; Ellis 2015). Human societies have made changes in local and global patterns of net primary productivity (Krausmann et al. 2013), and have caused widespread species extinctions (Dirzo et al. 2014; Pimm et al. 2014). Thus, the current environmental crisis has generated losses to diversity as a whole, and especially to the global economy due to the loss of ecosystem services and ecosystem functions (Groot et al. 2010). In a biosphere increasingly transformed by human societies, the science of ecology cannot advance as a predictive science without gaining the basic theoretical tools needed to investigate and understand ultimate causes, not just the consequences (Ellis et al. 2013). In this sense, the idea of infinite resources began to be seen as irrational. The subsequent environmental crisis took on remarkable proportions since the second half of the twentieth century (Holck 2008), mainly due to the over exploitation of natural resources with direct consequences for Biodiversity Conservation (Doughty 2013).

The conservation model that originated, and was promulgated in the US, established that nature and non-human animals must be protected from human interference, and that true conservation means setting aside tracts of land from which human settlements, and even humans themselves, may be excluded (Brinkerhoff Jackson 1994). However, it is necessary to direct efforts not only to protected areas (Conservation Units), but also to the conservation of managed areas and their local populations, as well as the establishment of co-management efforts (Huntington 2011). Consequently, the problem is not a lack of knowledge for effectively managing resources, but rather motivating humans to conserve (Anderson 1996).

The conservation of natural resources must be understood through the complexity of the relationship between the means (resources and conditions) and living beings, and their interactions, especially the active, negative and positive participation, of human beings. Maturana and Varela (1972) argue that a living being is coupled to its surroundings [i.e., a system coupled to other system(s)] and that the coupling is a condition of existence; if the coupling is lost, 
the living being will die. In this sense, if the coupling between the living system and its surroundings is a condition of existence, the human being, as a living system, cannot be explained as independent of its surroundings.

In this context, new proposals to understand environmental relationships with humankind are emerging (Brook and McLachlan 2008). Among these, the human bias in studies of ethnobiology emerges as the other side of ecology, integrating scientific knowledge with local traditional knowledge that has accumulated and been transmitted over time. Local Ecological Knowledge (LEK) is comprised of a body of important historical information (Berkes et al. 2000; Huntington 2000; Huntington et al. 2004), which is increasingly relevant for Biodiversity Conservation. LEK is based on insight into the workings of nature and, in many ways, converges closely upon the Western science of ecology (Huntington 2011; Pierotti and Wildcat 2000). Traditional peoples possess a wide range of biological information that can complement traditional academic knowledge in ecology, zoology, botany and conservation biology. This knowledge could be especially useful to studies of population biology, distribution patterns and relationships among abiotic factors (Albuquerque et al 2009; Brinkman et al. 2009; Huntington 2000), as well as to efforts of resource evaluation and management (Vandebroek et al. 2011), to name a few.

The activities of humans are often significant in shaping the lives and ecology of non-humans and the nature world (biodiversity). Thus, the inclusion and understanding of humans in studies of scientific ecology is urgently needed because it is indispensable for understanding major ecological questions.
My goal in this text was to review the source of ecology as a science and man's relationship with nature, seeking to assess the impartiality and neutrality of scientific research, and the new possibilities of understanding and consolidating knowledge, specifically regarding ecology. Thus, this study is based on these assumptions, without the pretence of being the last word. Towards this end, I will first provide a brief historical review of ecology as a science in order to further evaluate the contemporary possibilities of a humankind-nature interrelationship, particularly as it relates to improving the science of biodiversity conservation.

\section{Scientific ecology: a brief history and perspectives}

The most fundamental concept of ecology is its functional unit, the ecosystem. The basis of the concept of an ecosystem arose from the deconstruction of the conceptual barrier that separated living beings from nonliving minerals (life and no life) in the $16^{\text {th }}$ century, and the subsequent understanding of the processes of the synthesis and degradation of organic matter. In the $18^{\text {th }}$ century, vitalism (the vital principle), based on organic organization, replaced animism (Cartesian soul), which held that minerals, plants, animals and humans were created by God and, therefore, possess souls (see Ávila-Pires 1999). In the $19^{\text {th }}$ century, Lamarck's Philosophie Zoologique, originally published in 1809, contained the earliest account of a cohesive theory of the evolutionary process. Lamarck presented the idea of the inheritance of acquired characteristics, while later Charles Darwin (1859) developed an understanding of the relationship of organisms to natural selection. As a result, two main lines of 
inquiry emerged from the classic definition of ecology: the study of the interactions of organisms with their physical and biotic environment (Tansley 1914).

The notion of relationship between organisms and their environment emerged long before the consolidation of ecology as an independent science within biology late in the $19^{\text {th }}$ century. In a lecture at Sorbonne University in 1864, Claude Bernard, argued that to understand the life of an organism one must know its relationship to the general environment (Grmek 1997), and this external relationship is necessary for understanding an organism's vital manifestation. A few years prior, in 1859, Charles Darwin had already established some goals for this new emerging science, however he never proposed a name for it. Darwin's ideas about evolution and selective pressure provided the basis for the science of ecology, and opened the way for studies into support capacity, colonization, competition, competitive exclusion and biogeography, and was pioneering a notion of the concept of ecological niche (Darwin 1859), which would be fully developed decades later by Elton, Gause and Hutchinson. Ecological topics became investigative axes of this new science, which would, a few years later be recognized with an official name.

Several suggestions for the nomenclature of this new science were proposed in the 1860s. In 1865, Louis-Adolphe Bertillon, proposed the term mesology to describe the theory of the environment (Drouin 1993), and the English naturalist St. George Jackson Mivart proposed hexicology for the study of the relationships of organisms with the environment, the nature of the inhabited location, favorable conditions and interactions between benefactors and enemies; however, this latter term was never used (Kormondy 1969). In 1866, the German biologist Ernst Haeckel proposed the term ecology for the study of economics and the relationships of animals and plants with the environment (Haeckel 1866). It was at the end of the $19^{\text {th }}$ century, that the term took on its current meaning and developed as an independent science (Tansley 1914), with its own interpretations and research methods based on Cartesian and Newtonian mechanistics.

In 1887, Stephen A. Forbes published a paper, that would become a classic in ecology, in which he described a trophic web among the biotic components of a lake and that later served as a model for many studies on organization and biotic interactions, mainly in the USA (Ávila-Pires 1999; Forbes 1887). Other authors important to the maturation of the discipline of ecosystem ecology, include August Thienemann who introduced the terms producers and consumers in 1926; he also diffused the idea that life (Leben) and its surrounding world (Umwelt) should be considered as a unit. Charles Elton developed pyramids of numbers and the concept of the ecological niche (1927) and Eugene Odum, Alfred J. Lotka and Raymond Lindeman presented the idea of energy ecology. However, ecosystem ecology still has been criticized by analyzing the ecosystem in a holistic manner, although adopting a reductionist methodology (Wimsatt 1982).

The risk of applying partition analysis to complex systems is that it can disrupt the holistic unity of ecology, the concept of the ecosystem, as well as imped an understanding of certain phenomena and properties that result from a degree of complexity or organization (Hurrell and Albuquerque 2012). The partitioning of ecology based on observable variables can 
disfigure the essence of the process, and so care must be taken with simplistic models based on a Laplacian conception of a Universe that is reducible to simpler levels, so as not to forget the emergent properties that the holistic view of ecology provides.

The scientific revolution of the $17^{\text {th }}$ century was a watershed. Much of the new vision of the world at the time was due to the mechanistic and reductionist school of thought founded by René Descartes (15961650), which intended to explain biological phenomena in terms of the frameworks of physics and chemistry. This was not different in ecology. The discipline of ecology arose out of large questions about the distinction between the living and the non-living; the attempt to elucidate the chemical activities of fermentation, putrefaction and combustion, and plant physiology (Ávila-Pires 1999). Thus, with a better understanding of the process of photosynthesis, initiated by the English chemist Joseph Priestley (1733$1804)$ and the Dutch Johannes Ingen-Housz (1730-1799), the appreciation of the interactions among animals, plants and minerals solidified the ecology as a discipline. Ingen-Housz suggested that there existed a natural equilibrium between animals and plants; in the presence of light, plant chlorophyll would consume the carbon dioxide exhaled by animals, and release oxygen, which, in turn, would be used by animals (Ávila-Pires 1999). With this idea, Ingen-Housz helped to solidify the systemic unity of ecology.

Early in the $20^{\text {th }}$ century, several laboratory experiments applying reductionist methods were undertaken in order to solidify and standardize methodological approaches in ecology (Lotka 1925). However, the basic unit of this new science was the complexity of the relationships of organisms with the environment and so many models developed in these laboratories, such as those proposed by Lotka, Volterra, Gause, D'Ancona, among others, could hardly be applied to real situations nor be represented in nature. The application of the experimental method depends on a deep knowledge understanding of communities (Agrawal et al. 2007), thus demonstrating the error of seeking holistic knowledge through reductionist analysis of each factor involved (Wimsatt 1982).

In the 1940s there were several attempts to reduce the complexity of ecological relationships through the use of mathematical equations, which gave rise to theoretical speculations far-removed from the field and laboratory (Ávila-Pires 1999). This period was considered the golden age of theoretical ecology (Scudo and Ziegler 1978). Throughout the 1970s and 1980s, ecological modeling attracted (and still does), ecologists who sought (and still seek) to make ecology less descriptive and more predictive. However, the attempt to turn ecology into an exact science needs to be assessed considering the idiosyncrasies of the intellectual and cultural information of the respective epochs. There are compelling arguments for why reductionist research strategies cannot address for certain problems in ecology (Wimsatt 1982).

Thus, also in the 1970s, the field of deep ecology emerged (Naess 1973), derived from conservation biologists of more northern countries, with the intention of going further than the ecology itself, towards understanding it as a state of ecological consciousness, that is, that human and nonhuman lives have intrinsic value independent of utilitarianism (Naess 1984). Deep ecology has an extremely biocentric approach and, includes spiritual, ethical and moral influences, especially with regard to a dichotomous and dialectical relationship 
between man and nature. It holds that humans are related to nonhumans and irrevocably connected to the natural world (Pierotti and Wildcat 2000), however, human intervention in ecological processes was not well being perceived. During 1970s, the human participation as key actor in perturbation process, while at the same time being a fundamental agent in the recuperation of systems start to be considered, understanding the human being to be intrinsic to ecological complexity.

During the 1970s and 1980s, Ramón Margalef and his disciples from the Barcelona school, introduced in ecology the concepts of nonlinear thermodynamics of irreversible processes, contributed to the complexity in its triadic model of competition, where the analysis of the two competitors adds that of the resource for which they compete (Margalef 1980; Margalef 1986). Margalef did not enter into the practical level of complexity science, but was one of the pioneers in relating ecology to complexity (Flos 2005).

In the 1980s, ecology resurfaced as a result of studies about capitalism and utilitarianism, going beyond the consequences of environmental destruction, and addressed the relationship between man and environment. Due to human impacts to natural environment having consequences directly affecting human societies (Ellis et al. 2013), a new worldview appeared (ecological sensitivity as a social fact), driven by scientific and metaphysical questions.

Nonetheless, ecological models and ecosystem theory experienced difficulty integrating the human being into analyses. These theories were intended for understanding pristine models, in spite of the fact that almost all of the world's landscapes (around three-quarters) had already been transformed into anthropogenic biomes (anthromes) by human occupation and land use (Ellis and Ramankutty 2008; Ellis 2015). Ecologists have preferred to leave the human being out of their considerations of ecosystems, because their inclusion introduces sociocultural variables that require complex analyses (Diegues 2000). With the exclusion of the human being from ecological analyses, the ubiquitous modifications caused by human activity is considered an external action, and always with a negative impact on nature.

The validity of widely accepted environmental beliefs should be questioned, such as, for example, beliefs about primary forests or about global warming analysis. Scientific discoveries are often accepted as if they were absolute truths. A scientific truth, however, is a conclusion drawn from a limited set of data; it is an explanation of what scientists understand about a subject at a particular point in time, based on their own qualifications and interpretations (Prigogine 1994). An "absolute truth" may be replaced by another truth in light of new information that does not fit the previous paradigm.

Ecology is a theory-laden science (Mclntosh 1987). However, many ecological theories have been replaced over time (Graham and Dayton 2002). Concepts and laws have been questioned, tested and subsequently falsified (Brook and McLachlan 2005, Graham and Dayton 2002). The concepts of climax communities and ecological equilibrium, for example, have been used for nearly an entire century without being questioned, until some 25 or 30 years ago (McCune and Allen 1985; Dublin et al. 1990). Currently scientists work with the theory of non-equilibrium or with systems that are far from equilibrium, in thermodynamic terms (Reice 1994). 
Increasingly, nature is recognized as a state of continuous change (Pickett et al. 1991), with some changes being random and independent of each other, and others induced by human beings. Other theories of ecology have also been challenged over the years, such as, the theory that areas with greater soil fertility would have greater diversity (i.e. the higher the nutritional value of the soil, the greater the number of plant species). However, it was later shown that physical environments with intermediate nutritional availability were those that had greatest diversity (Theory of Intermediate Soil Fertility, Tilman 1986). In a similar manner, many other theories have been falsified or challenged over time, including the theory of complexity and stability (Chesson 2000); the theory of diversity versus area (Losos and Schluter 2000; Whittaker and Fernandez-Palacios 2007); the theory of a predator-prey dynamics (Krebs et al. 2001), among others.

Much of the work that are done in ecology is still at the level of testing new hypothesis of specific phenomena, but is at risk of generating reductionist explanations, because complex phenomena require complex explanations; otherwise, the explanatory models become reductionist (Morin 1980, 1985, 1990). In an opposite and contemporary way, the central issue of ecology is the existence of ultra-complex webs involving different trophic levels and environmental factors or the existence of semi-independents interconnected microsystems (Agrawal et al. 2007; Allen and Hoekstra 1993). However, this complexity is not taken into account when the human being is included in this process. Analysis of ecology should not include humans as just a research subject, but also consider the consequences of their actions. Humans are also perceived as those who can influence knowledge construction. In this sense, the neutrality of the researcher, as required by the positivist paradigm is a complicating requirement and distorts the essence of the complexity of ecology (Allen and Hoekstra 1992).

Finally, and in the contemporary way, ecology that develops outside research centers is often used interchangeably as "environmen" and "nature". This improper use can transform the science of environmental relationships (complex interactions) into ambiguities and weaknesses that are aimed at heterogeneous concepts (Guerra Sierra and del Hierro 2008).

\section{The realism illusion - uncertainty requires other perspectives}

Understanding contemporary science is an exercise that begins with the history and heritage of the hegemony of one kind of knowledge: the positivist view. Since the $17^{\text {th }}$ century, scientific research was marked by the Cartesian paradigm or positivism/rationalism. The most prominent rationalists of the $17^{\text {th }}$ century were René Descartes (French), Baruch Spinoza (Dutch/Portuguese) and Gottfried Leibniz (German), who suggested that the world could be transformed into a mathematical framework. Since then, Western science has subscribed to a "mechanistic" view of the universe, wherein the world is a machine-like system with interconnected parts governed by laws that produce well defined and controllable outcomes (Goerner 1994). This view led to the attempt to discover nature itself, its laws, and its determinism in order to predict and monitor natural phenomena. Determinism was, and is, desirable for explaining physical phenomena for which certain regularity is expected. However, it is 
possible to escape the tough Determinism of Newtonian mechanics.

Determinism, it must be understood, is opposed to the uncertainties of the future, and is influenced by the transformations of history. With the advent of quantum physics, scientific methods began to be questioned less, especially considering the notion of irreversibility of time, as defended by llya Prigogine (1994). Thus, new perspectives are expected by the premise of uncertainty.

The limits set by the probability of deterministic uncertainties and the content of physical reality reveal a new complexity, where the relationship between observer and the object of study (neutrality) loses its dichotomous character and assumes a continuum. This continuity does not necessarily lead to a merger between the subject and the object, because the rigor of the scientific method and the fidelity of observation impose their displacement (Bohr 1991). According to Niels Bohr (1991), about the notion of complementarity in quantum physics "any situation in which the interaction is at the same time negligible and uncontrollable escapes the classical problem of objectification".

One of the great and still indissoluble myths in science is related to neutrality and objectivity. On the one hand, the idea of neutrality, the non-inclusion of subjective aspects of research or the establishment of results and interpretations without researcher interference, is still endorsed by scientific precepts (Almeida 2012). The idea of neutrality, in fact, is unique to modern Western science and is just a component of research that does not allow interpretations and representations with thin lines of subjectivity and idiosyncrasies of human knowledge and practices in scientific production. On the same hand, the defense of objectivity is a product of positivist hegemonic science in a culture of a capitalist society that longs for immediate results. However, the relationship of objectivity to science is nothing more than the imposition of one particular subjectivity to the exclusion of all others. Especially, in areas that relate more directly to human life, a perfectly deterministic point of view cannot be expected, leaving little room for human freedom, unless it is made with a purely subjective notion. From this point of view, man is not an exception to nature, but is certainly a key feature of it (Bateson 1972; Euvé 2005). According to Prigogine (2001), "whatever we call reality, it is revealed to us only through the active construction in which we participate".

The separation of the researcher from the object of study (in ecology, the separation of man from nature) is one of the pillars of the scientific method, where the researcher should define the research object independently of himself. However, there is no categorical separation or, watertight division between researcher and object (Euvé 2005), otherwise this understanding would allow the illusion of objectivity and neutrality (reality). The researcher (subject) does not occupy a transcendent position in relation to the world; the subject cannot describe an object abstracting of the bond that unites them (Prigogine 1994).

The approach of positivist science is to collect an abundance of data prior to making conclusions regarding a topic or problem. There are countless examples of research into natural (ecological) phenomena without this certainty of understanding, plus, the methods selected to examine a particular problem, can have a strong influence in determining the answer. In this sense, scientists are expected to provide clear and explicit explanations of both the process of research and the results obtained so that the 
investigation can be replicated. This position is considered to reflect the "real world", and thus, the methods employed become standardized, precluding investigators from seeking more information that could lead to different interpretations. The partiality towards this view (absolutist position of positivism) ignores other possibilities and other perceptions of the same reality, nevertheless in a constant changing world, there will always be uncertainties. All knowledge of the world is not only private, but also provisional, hypothetical and uncertain (about the irreversibility of time).

Classical science requires that all knowledge from observation and experience be considered, without reference to human. Although, according to Gaston Bachelard (1996), "scientific knowledge is not a pleonasm of experiment". Thus, one can speak of the dialogical nature of the relationship between scientific discourse and the real. In these sense, Emanuel Kant (1966) models all understanding of reality as eminently having a human foundation. He has argued that "all spatio-temporal objects are appearances, and since they are the only objects given to us, therefore all objects are appearances (transcendentally ideal) through the lens of human sensibility". Contemporary science proceeds in a direction opposite to the ontology of the real, but without completely abandoning the real sense. For Bergson (1990) "the reality is only a particular case of the possibility".

Mental models are characterized as incomplete representations of reality (Jones et al. 2011), and are models of dynamic representations that change over time called the cognitive representations. For George Berkeley, one of the defenders of idealism, the world only exists as an idea, a kind of consensual hallucination (Berkeley 1871). Even the physical reality perceived by the senses can deceive us, such as, for example, the inverse codification of an image that our brain needs to perform so that we know where things really are. Anyway, our real world is a universe from which an observer can never eliminate disorder or himself (Morin 1999). For Maturana (1977), an important Chilean neuroscientist, "reality is a phenomenon constructed by an observer in relation to the environment". So, we can only attain knowledge of appearances, never of things in and of themselves (Kant 1966). According to the Austrian physicist Erwin Schrodinger "all we know, we know from our own experience" (Schrodinger 1997). Furthermore, Edgar Morin (1999) comments, "we only produce knowledge beginning with ourselves, from our cognitive models, which are known by cognisance of our own autonomy". In this sense, assumptions, theories and interpretations by scientists are the result of cognitive attitudes experienced and consolidated by them (Hurrell 1987). Finally, natural reflection can assist in resolution and clarity of results; however, researchers generate explanations from their own theoretical framework.

The concept does not arise of scientist's ability to debug errors and illusions in favor of a truth that then unfolds (Foucault 1995). According to Bachelard (1996) "we always know in negation to previous knowledge, so there are no new truths, only the first error". Truth is in constant motion being associated with the history and context of memories and culture of a particular time, that is, truth is a mirage that cannot be realized because the world we know is created by us (Eisner 1990). According to Multifocal Intelligence Theory (MIT), the virtuality of thought shows that absolute truth is always an unattainable end (Cury 2013). Thus, truth is an ongoing dialogue between the subject and nature, 
with questions being formulated to determine answered. An active questioning. In this sense, contemporary epistemology clarifies that the subject is not the scribe of nature. Nature is interrogated, and the scientific method is not content to passively record data.

Some authors (Morin, Eisner, Maturana, Varela and many others) point out that science is a human construct, which is the exact opposite of positivism, that is, science is not a soliloquy, or even just a dialogue with other scientists, but a constant construction, which must take into account the complexity of human relationships. Nevertheless, materialistic view (partial understanding of a phenomenon), in general, works well, and can bring benefits to the evolution of a theory regarding the human-environment relationship. This is not to say, however, that it is factual to reduce the complexity of this relationship without considering the influence of cultural relationships (Hurrell 2014).

The complexity of the humanenvironment relationship

The technical and methodological advancement of humanity does not always follow a path of Cartesian reductionist absolutism. The great achievements of humanity over, at least, the last ten thousand years, are referred to as the "Neolithic paradox", distinct from the positivist methodologies of the $16^{\text {th }}$ and $1^{\text {th }}$ centuries (Fores 1983). For a long time, human knowledge relating to nature was sufficient for clarifying the partial truths that posteriorly it would "falsified" by the new positivist science (Fores 1983). However, with the advent of positivist science some attitudes, such as faithful credulity, aversion to doubt, boastful knowledge, acceptance of partial knowledge, among others, prevented the union of human understanding with the nature of things (Adorno and Horkheimer 1985).

Positivist reductionism constantly tries to separate component facts in order to rearrange them later and induct generalizations. One of the great emblematic expressions of the $17^{\text {th }}$ century reductionism was "divide and rule," used as a formula by Machiavell (1469-1527) to dominate cities; and by Descartes (1596-1650) to dominate intellectual challenges. In this sense, all the cruel rigor of the scientific method was invested in favor of contemplating a universe of simplicity, clarity, calm, purity, eternity and peace, and, evading the everyday, world experience, personal existence, and reconciling monotony, instability, complication and noise (Einstein 1979). However, a price to pay, according to Prigogine (1994), is that "the more the world becomes transparent, the soul becomes opaque".

Plurality and human complexity present a new way of seeing truth and reality. What is required are pluralistic ways of thinking about the world and actions to change it (Kuhn 1962). New paradigms are emerging from quantum physics, philosophy, human sciences, chaos theory, complexity and so many other sources. What can a new alliance between the history of men, their knowledge and their science tell us?

On these emergent properties of the arrow of time (irreversibility), which bifurcates and distinguishes the stories of the universe, matter and life, the human condition is imbricated by multiplicity (Morin 1973, 1999). The hybridization of physical, biological and metaphysical, collective and individual, and natural and artificial phenomena allows the development of a new paradigm of systemic complexity and of 
multiple understandings (Morin and Le Moigne 2000), which includes uncertainty, unpredictability, incompleteness, and instability (May 1989). This complexity is more properly recognized as a self-ecoorganized system with emergency features, which it creates itself, and that is far from equilibrium (Morin 1999; Morin and Le Moigne 2000).

Therefore, Lévi-Strauss comments: "the scientific thinking should be adjusted by one side by the perception and imagination and by other side by displaced manner, that is, necessary relationships that constitute the object of all science", that is, must be achieved in two different ways: one closer to sensitive institution and another farthest (Lévi-Strauss 1964). A scientific fact, in and of itself, is the result of the sum of selections made throughout the research process (Brook and McLachlan 2005). Thus, there is no way to separate the human from the scientific, the internal from the external of the scientific activity.

In this sense, the human presence in environmental relationships (the ecology), both as a study object and as an observer, interpreter and source of discussion offers new possibilities. This is a period of postnormal science (Toledo and BarrreraBassols 2008), according to Kuhn's terminology (1962) with the confluence of generic works with the influence of mathematics and Newtonian classical physics. According to Kuhn (1962), theories are not falsified by direct comparison with nature, but by adopting new paradigms, which he called "scientific revolutions" or "extraordinary science". This new era of science is consistent with the field of complexity, in which issues complex humanists it integrates actions and concepts, and possibly it involves the ecology. We may forward to "asleep humanism" of Nietzsche (2000), in which it pulsates and yearn for it return.

\section{Approach of scocial-ecological system - ethnobiological studies}

Some sciences that focus on human beings, such as human ecology (Campbell 1985; Neves 2002) and ecological anthropology (Hardesty 1979), approaches relationships between human beings and their environmental, on the other hand, the biocultural ecology (Buxo-Rey 1980) and ethnobiology mainly evidence the complexity of the relationships between human beings and their surroundings, involving abiotic and biotic interactions, as well as social and cultural dimensions (Albuquerque and Hurrell 2010). In addition, and in a contemporary way, ethnobiology can serve as a mediator for multicultural dialogue and complex of environmental issues.

In general, ethnobiology is characterized as a holistic and multidisciplinary discipline, and so possesses many definitions with different emphases and approaches, although always with interest into interrelationship between human groups and the natural environment, along with the changes over time (Hurrell and Albuquerque 2012), that is, the researches of ethnobiology investigates the complex set of relationships between biota and past and present human societies (Stepp 2005). Thus, ethnobiology is the study of the ideas, knowledge, beliefs and actions of a given society about nature (Ellen et al. 2000; Nabhan 2009; Toledo 1992; 2002). To Marques (2001), ethnobiology can be described as the scientific understanding of the connections between humans (culture and knowledge) and their environment.

The propositions of ethnobiology have many different goals, which result in lines of 
investigation into the relationships humans with specific areas of ecological knowledge (Sturtevant 1964) or with ecology itself. Moreover, several areas of biology are investigated in ethnobiology studies, such as ethnobotany, ethnozoology, ethnoornithology, ethnoichthyology, among others. Among these lines of investigation, the ethnobotany and ethnozoology are worth mentioning; a major review of the definition and key concepts of ethnobotany were provided by Hurrell and Albuquerque (2012) and a review of ethnozoology by Alves (2012). In general, the historical view of ethnobotany and ethnozoology has been of a utilitarian bias, with humans being considered disconnected from the ecosystem. This perspective, however, cannot be comprehended in the context of biocultural ecology, whose premises include human beings, as both culturally and biologically part of ecosystem (Albuquerque and Hurrell 2010; Hurrell 1990; Hurrell 2014).

The proposal to integrating ecological concepts into ethnobotany emerged in the 1940s (Ford 1978; 1994). However, was in 1980s that the link between ethnobotany and ecology really started (Albuquerque and Hurrell 2010). The ethnobotanical approach of looking at people-plant relationships from the theoretical context of general ecology can be useful (Albuquerque and Hanazaki 2009; Peroni et al. 2010), due the ethnobotany, in the particularistic sense (Albuquerque and Hurrell 2010), to be similar to ecology in their complexity and interdisciplinary (Hurrell and Albuquerque 2012).

Some pioneering works have made strong and well-structured connections between fields of ethnobiology and the theoretical and methodological frameworks of ecology (see details in Albuquerque and
Medeiros 2013; Albuquerque et al. 2015a; Albuquerque and Hurrell 2010; Hurrell and Albuquerque 2012). For Alves et al. (2010), the association of ethnobiology with ecology adds complexity, especially when considering ecology as an interaction between the natural and social sciences (Odum 1977). Thus, rather than adopting purely ecological methods and techniques, this proposal incorporated ecology into its conceptual framework with the understanding that ecology is the science of the complex relationships between living beings (human beings included) and their environments (sensu lato), as the result of an evolutionary process (Hurrell 2014).

The complexity of the relationship between people and the environment often involves adaptive responses to ecological and evolutionary forces (Albuquerque and Medeiros 2013; Hurrell 2014; Hurrell and Albuquerque 2012). The application of ideas regarding evolution, through deductive reasoning, to human societies and culture, was first considered by Herbert Spencer (1820-1903) in the $19^{\text {th }}$ century. Recently, one branch of ethnobiology has realizing studies that follow ecological assumptions and theories within an evolutionary context, an approach termed "evolutionary ethnobiology" (Albuquerque and Medeiros 2013; Albuquerque et al. 2015a; Hurrell and Albuquerque 2012). In these studies, the complex relationship between humans and their environment are investigated within the context of evolutionary biology. This type of approach reflects the current state of the epistemological evolution of ethnobiology and increasingly solidifies the perspective of a complex relationship between humans and their environment. The use of evolutionary principles could unite the theoretical concepts of ecological systems with those of cultural systems, because both systems 
have an open nature, interacting strongly and adjusting their structure and organization, which could indicate a coevolutionary relationship between them, referring as a social-ecological system (Berkes and Folke 1998; Ferreira-Júnior et al. 2011; Folke 2006; Nascimento et al. 2015).

Among the diverse research lines in evolutionary ethnobiology, some are associated of ecological theories applied to local (or traditional) knowledge, wisdom and, studied societies (see details in Albuquerque et al. 2015a). Studies, for examples, with ecological resilience (Carpenter et al. 2001; Gunderson 2000; Holling 1973; Reldman and Kinzig 2003), ecological redundancy (Walker 1992; Wellnitz and Poff 2001), Optimal Foraging Theory (MacArthur and Pianka, 1966; Martin 1983; Perry and Pianka 1997; Pyke 1984; Sih and Christensen 2001), are investigated on the field of cultural history (cultural systems) (Albuquerque 2006; Ferreira-Júnior et al. 2013; Folke 2006).

The contribution of local knowledge to scientific-academic knowledge of ethnobiological studies has been recognized since late in the 20th century (Posey 1987; Hunn 2007). In ecological studies, the use local (or traditional) ecological knowledge is promisor to better understanding about the process maintainers of biodiversity (Albuquerque et al. 2009; Sánchez-Azofeita et al. 2005), approaching studies of perception and representation of landscapes; temporal and spatial changes in target populations; use and management of natural resources, among others.

The other side of ecology: integrating local ecological knowledge with scientific knowledge for biodiversity conservation
Current discussions regarding the environmental crisis have taken place not only in the fields of ecology, geography, engineering and economics, but also in the social sciences including anthropology, and ethnobiology. In fact, the environmental crisis involves ecological and social problems in the same context (Walker et al. 2004). In the last three decades, discussions regarding conservation and the maintenance of the processes that define biodiversity have become essential in scientific community (Holck 2008). According to Castro et al. (2010), such discussions are based on understanding of two fundamental aspects of biodiversity: (1) a multidisciplinary approach is necessary for understanding the interrelationships among ecological, economic and social systems in an integrated manner (Berkes and Folke 1998); and (2) conservation cannot be based solely the on establishment of areas conserved (Danielsen et al. 2007), because managed and impacted areas represent a large percentage of the world's ecosystems (Ellis 2015; Pimentel et al. 1992).

The traditional models of conservation science have been marked by methodological reductionism (Brinkerhoff Jackson 1994), however, the conservation processes and management of natural recourses should not proceed in a reductionist direction. The relationship between nature and human beings incorporates a social perspective in processes changing, including how they are perceived by those who cause the own changes (Garrido-Pérez and Glasnovic 2014; Rozzi 1999). Human experience with nature can provide numerous insights into the processes that maintain and transform ecological equilibrium (Garrido-Pérez and Glasnovic 2014). The reductionist Cartesian view of positivist researchers can limit the 
scope of interpretations of natural phenomena and their relationship with human beings. The same situation can be seen and perceived by different individuals with different life experiences and values, that is, is possible to have more than one explanation for the same phenomenon based on the theoretical premises of the researcher (Maturana 2007) and/or the local knowledge. Thus, the conservation aspects go further this perspective (Diegues 2000). It is clear that humans are not unrelated to nature, and can manage, plan and execute actions related to it; inherently we are, and belong, to the complexity of ecology.

According to Leff (2002), from this perspective "the environmental crisis is not an ecological crisis, but a crisis of the reason", or, in other words, a crisis of the concept of dissociating nature from society (Capra 2004). It is necessary to seek the other side of the environmental crisis; the maintenance of biodiversity is not only due to natural processes, but also to actions of human societies, their cultural relationships, and their ecological knowledge (Capra 2004; Diegues and Arruda 2001).

The ecological knowledge emerged from the interaction between the human being and their local environmental can be defined as Local Knowledge Systems (LKS), which is defined as a set of knowledge, practices, beliefs, traditions about the environment developed and sustained by indigenous and local communities (Vandebroek et al. 2011). In the literature, several terms have been used to refer to this type of knowledge, including Traditional Ecological Knowledge (TEK) (Berkes 1999; Berkes et al. 2000; Huntington 2000), non-Traditional Ecological Knowledge (Hurrell 2014) and Local Ecological Knowledge (LEK) (Berkes 1993).

Traditional Ecological Knowledge represents the cumulative body of ecological knowledge and beliefs passed down through generations via cultural transmission and in the shared practices, and can be dynamic and flexible in face of fluctuations of that environment (Berkes et al. 2000). Although views of TEK are considered "traditional," with the negative connotation of being outdated or primitive, and thus of little use to solve problems of modern society (Beckford and Barker 2007), this should not be taken to mean that they cannot change since the use of the term "traditional" simply implies the repetition of a fixed body of data.

Local Ecological Knowledge or NonTraditional Ecological Knowledge represents experiential knowledge derived from interactions with the local environment and is characteristic of culturally heterogeneous (pluricultural) contexts (Berkes et al. 2000; Huntington 2000; Huntington et al. 2004; Hurrell 2014). The ecological knowledge of human communities that interact with resources can be profound, accurate and valid and should be incorporated into ecological studies and assessments of the conservation status of species (Albuquerque et al. 2009; Alves and Souto 2015; Helfman 2007; Sánchez-Azofeita et al. 2005).

In fact, both of these sources of knowledge are relative terms, not mutually exclusive (Hurrell 2014), although Ruddle (1994) considered that the term 'local' is less problematic, and thus a more practical description or identifier of the relevant people and their knowledge. In addition, Brook and McLachlan (2008) also considered LEK as more inclusive term. Thus, I will use it for the purposes of this review.

An individual person's ecological knowledge depends on their direct experience with the environment in which they live, as well as on the learning processes they participate in with other 
community members (Rudlle 1993). According to Toledo and Barrera-Bassols (2010), an individual builds their knowledge through historical experience (what was said), socially shared experience (what others say) and personal experience (what an individual observes for themselves). Thus, understanding the choices made by people in their relationship with the environment requires knowledge of how these people conceive and classify their midst. In addition, the knowledge (environmental) to be understood is inextricably linked to belief system (kosmos), body of knowledge (corpus) and production practices (praxis) of traditional knowledge (Toledo 1992; 2001; 2002; Toledo and Barrera-Bassols 2008). The studies of the kosmos-corpus-praxis complex (K-C-P) integrate the LEK within theorizing processes, through symbolic meaning, representation and production at various spatio-temporal scales (Toledo and BarreraBassols 2010), to the use and management of the landscape and natural resources (Barrera-Bassols and Toledo 2005; ReyesGarcía and Martí-Sanz 2007).

Because of its peculiarities, contemporary ecology tends towards interdisciplinary integration, incorporating local ecological knowledge (LEK) into the production of scientific ecological knowledge (SEK) (Hurrell and Albuquerque 2012; ReyesGarcía et al. 2010). This integration promises to produce a greater awareness of relationships over knowledge, in order to balance the excesses of positivist science, without linking with environment. LEK can provide information about the contemporary status of target species and ecological resources (Turvey et al. 2014), beside, it can be a guide for autoecological studies of species of economic interest, or provide complementary information to investigations into species distribution, ecophysiology and ecology (Huntington 2000; Huntington et al. 2004). In this sense, there is a need for complementary studies that incorporate local ecological knowledge and scientific ecology (Figure 1). This complementarity is known as the post-classic period of ethnobiology (Clément 1998) and is considered an important tool for decisions regarding conservation strategies and local management plans (Huntington 2011).

\section{FINAL REMARKS}

Ecology, like other scientific disciplines, emerged from a Cartesian scientificacademic context, which influenced its methodological and theoretical basis. However, advancement in the understanding of the complex interrelationships observed and experienced over time by many professionals, has allowed a clearer comprehension of the complexity of the conceptual and methodological basis of ecology. The inclusion of a humanistic bias as the object of study and complexity generator is pungent matter in new theoretical and methodological approaches to ecology, as well as biodiversity conservation processes.

To meet the objectives of biodiversity conservation in their entirety and maintain natural resources it is necessary to diagnose the impacts to resources, their causes, processes and consequences and their indirect effects on economy, institutions, individuals and social behaviors (Diegues 2000). It is necessary to direct efforts not only to protected areas (Conservation Units) (West et al. 2006), but also to managed areas and in support of local people (Berkes 2004; Wells and McShane, 2004), which currently account for most of the landscapes in the world (Ellis 2015). Thus, a new 


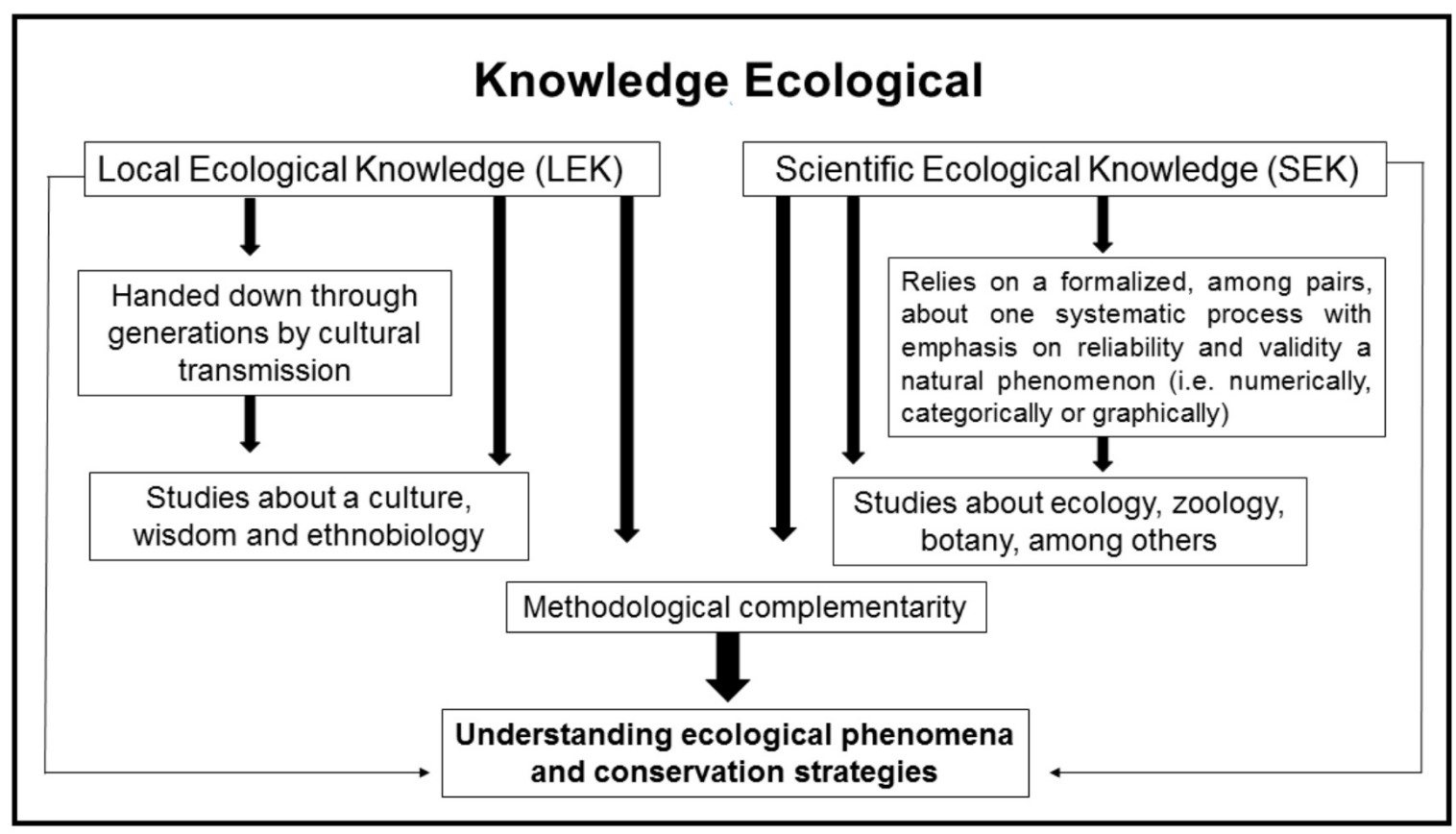

Figure 1. Representation of a framework to guide empirical studies when considering methodological complementarity. The goal in this framework is not necessarily to cover every possible process, but, instead, to highlight the way that are needed to better of knowledge ecological and to understanding ecological phenomena and conservation strategies.

discussion seems have become established at this time - the role of the community in the conservation of natural resources, with use of the local ecological knowledge to targeting the actions (Mittermeier et al. 2003). The biological and cultural impacts that our actions have had, and still have, on the environment and on our own species has often been the driver of the rise or decline of civilizations throughout human history (Diamond 1991; Diamond 2005).

It is necessary to dissolve the dualism between man and the environment so that environmental issues can be resolved (Nabhan 2001). The conservation biology science, inherently, need of the relationship between human being and the environment as well as of the perception of man, acting clearly as a negative modifier, but undoubtedly, of form positive in their recovery actions, management and enhancement of integrative relations (complex complementarity).

The use of traditional ecological analyses in conservation studies can be insufficient if it is disconnected from qualitative data on the investigated human populations and their complexity (Berkes 2004; Berkes et al. 2000; Danielsen et al. 2007). The use of the LEK addresses a level of reality and correspond to the universe of meanings, motives, beliefs, aspirations, values and attitudes, which corresponds to a deeper space of relationships, processes and phenomena that cannot be reduced to the operationalization of variables (Minayo 2003). In fact, the integration of the LEK with the SEK do not cancel each other out, but complement each other, providing different insights to the same reality (Minayo and Sanches 1993; Reyes-García et al. 2010; Vandebroek et al. 2011). Apart from opposition and the substitution of knowledge, it is necessary to speak of 
complementarity (Figure 1).

Thus, the progress of acquiring knowledge should always be a reorganization of models to understand the world and never by their deletion or replacement. However, one has to take into account of Popper's ideas, that any description of a phenomenon involves process of a selection (Popper's 1959) thus the holistic approach (complementarity) should be viewed with caution and directed only for some knowledge phenomena.

The continued development of integrating LEK into science ecological frameworks for understanding environmental change depends on the advancement of tools for aggregating observations in a way that satisfies the demand for quantitative rigor in the ecological sciences but, critically, seeks to avoid inappropriately reductionist treatments of resource users' knowledge (Beaudreau and Levin 2014). LEK is not inherently based only on concepts about nature, but also involves public politics (politic ecology) and ethics questions (Pierotti and Wildcat 2000). Finally, there is a lot to be learned from these knowledge, not only from the knowledge itself, but also from the philosophical meanings embedded in that knowledge (Vandebroek et al. 2011).

Anyway, according to Germano and Kulesza (2010) it takes a new alliance that aims to meet polyphonic interests, the wishes of local communities, society as a whole and the scientific community itself. In this sense, human bias is of the utmost importance in the search for answers to ecological questions, especially when we integrate the Local Ecological Knowledge into our ecological analyses with goal to improve the processes maintainers of the biodiversity.

\section{ACKNOWLEDGEMENTS}

I would like to thank the anonymous referees for detailed and wise advice and the $\mathrm{CNPq}$ for the financial support and for productivity grant awarded.

\section{REFERENCES}

Adorno T, Horkheimer M (1985) Dialética do esclarecimento: fragmentos filosóficos. Tradução: Guido Antônio de Almeida. Jorge Zahar Ed. Rio de Janeiro, RJ.

Agrawal AA, Ackerly DD, Adler F, Arnold AE, Cáceres C, Doak DF, Post E, Hudson PJ, Maron $J$, Mooney KA, Power M, Schemske D, Stachowicz J, Strauss S, Turner MG, Werner E (2007) Filling key gaps in population and community ecology. Frontiers in Ecology and the Environment 5(3): 145-152.

Albuquerque UP (2006) Re-examining hypotheses concerning the use and knowledge of medicinal plants: a study in the Caatinga vegetation of NE Brazil. Journal of Ethnobiology and Ethnomedicine 2(1):30.

Albuquerque UP, Hanazaki N (2009) Five problems in current ethnobotanical research and some suggestions for strengthening them. Human Ecology 37: 653-661.

Albuquerque UP, Araújo TAS, Ramos MA, Nascimento VT, Lucena RFP, Monteiro JM, Alencar N, Araújo EL (2009) How ethnobotany can aid biodiversity conservation reflections on investigations in the semi-arid region of NE Brazil. Biodiversity and Conservation 18: 127-150.

Albuquerque UP, Hanazaki N (2010) Recent Developments and Case Studies in Ethnobotany. Sociedade Brasileira de Etnobiologia e Etnoecologia/NUPEEA, Recife.

Albuquerque UP, Hurrell JA (2010) Ethnobotany: one concept and many interpretations In Albuquerque UP, Hanazaki N (orgs.) Recent Developments and Case Studies in Ethnobotany. Sociedade Brasileira de Etnobiologia e Etnoecologia/NUPEEA, Recife, pp. 87-99. 
Albuquerque UP, Medeiros PM (2013) What is Evolutionary Ethnobiology? Ethnobiology and Conservation 2: $1-4$ doi: http://dx.doi.org/10.15451/ec2013-8-2.6-1-04

Albuquerque UP, Medeiros PM, Casas A (2015a) Evolutionary Ethnobiology. Springer Cham Heidelberg, New York Dordrecht London. doi: http://dx.doi.org/10.1007/978-3-319-19917-7

Albuquerque UP, Soldati GT, Ramos MA, Melo JG, Medeiros PM, Nascimento ALB, Ferreira Júnior W S (2015b) The Influence of the Environment on Natural Resource Use: Evidence of Apparency, In: Albuquerque UP, Medeiros PM, Casas A Springer Cham Heidelberg, New York Dordrecht London, pp. 131-147 doi: http://dx.doi.org/10.1007/978-3-31919917-7

Albuquerque UP, Alves RRN (2016) Introduction to Ethnobiology. 1.ed. Switzerland: Springer International Publishing

Allen TFH, Hoekstra TW (1992) Toward a Unified Ecology Columbia University Press, New York

Allen TFH, Hoekstra TW (1993) Toward a Unified ecology Columbia University Press, Reprint Edition, New York

Almeida, MC (2012) Ciência da complexidade e educação: razão apaixonada e politização do pensamento. EDUFRN, Natal, RN

Alves AGC, Souto FJB, Peroni N (2010) Etnoecologia em perspectiva: natureza, cultura e conservação. NUPPEA, Recife

Alves RRN (2012) Relationships between fauna and people and the role of ethnozoology in animal conservation. Ethnobiology and Conservation 1:1-69.

Alves RRN, Souto WMS (2015) Ethnozoology: A Brief Introduction. Ethnobiology and Conservation 4 (1):1-13.

Anderson EN (1996) Ecologies of the Heart. Emotion, Belief, and the Environment Oxford University Press, UK

Atlan H (1993) In Passis-Pasternak, G (entrevistas) Do caos a inteligência artificial: quando os cientistas se interrogam. Editora da Universidade Estadual Paulista, Trad. Luiz Paulo Rouanet, São Paulo

Avila-Pires FD (1999) Fundamentos Históricos da Ecologia. Holos, São Paulo
Bachelard G (1996) A formação do espírito científico: contribuição para uma psicanálise do conhecimento. Editora Contraponto, Tradução de Estela dos Santos Abreu, Rio de Janeiro

Barnosky AD (2014) Palaeontological evidence for defining the Anthropocene. Geological Society, Special Publications 395:149-165.

Barrera-Bassols N, Toledo VM (2005) Ethnoecology of the Yucatec Maya: Symbolism, Knowledge and Management of Natural Resources. Journal of Latin American Geography 4(1): 9-41.

Bateson G (1972) Steps to an ecology of mind. 1 ed. Ballantine Books, New York

Beaudreau AH, Levin PS (2014). Advancing the use of local ecological knowledge for assessing data poor species in coastal ecosystems. Ecological Applications 24(2): 244256.

Beckford C, Barker D (2007) The role and value of local knowledge in Jamaican agriculture: adaptation and change in small-scale farming. Geographical Journal 173(2): 118-128.

Bergson H (1990) Matéria e memória. Ensaio sobre a relação do corpo com o espírito. Tradução Paulo Neves da Silva. Martins Fontes, São Paulo

Berkeley G (1871) The Works of George Berkeley (eds). Fraser AC, Londres. Traduzido por Marques JOA (2008) Cadernos História e Filosofia da Ciência 18: 447-584.

Berkes F (1993) Traditional Ecological Knowledge in Perspective In: Inglis JT (Ed.), Traditional Ecological Knowledge: Concepts and Cases, 1 ed. International Program on Traditional Ecological Knowledge/ International Development Research Centre, Ottawa, Canadá, pp. 1-10.

Berkes F (1999) Sacred Ecology: Traditional ecological knowledge and resource management, 1 ed. Taylor \& Francis, Philadelphia, USA

Berkes F (2004) Rethinking Community-Based Conservation. Conservation Biology 18(3): 621630.

Berkes F, Folke C (eds) (1998) Liking Social and Ecological System. Cambridge University Press, Cambridge 
Berkes F, Folke C (1998) Linking social and ecological systems for resilience and sustainability In: Berkes F, Folke C (eds) Linking social and ecological systems: management practices and social mechanisms for building resilience. Cambridge University Press, Cambridge, pp 1-26.

Berkes F, Colding J, Folke C (2000) Rediscovery of traditional ecological knowledge as adaptive management. Ecological Applications 10:1251-1262.

Bohr N (1991) Physique atomique et connaissance humaine. Gallimard, Paris

Bramwell A (1989) Ecology in the 20th century: a history. Yale University Press, New Haven, Connecticut, USA

Brinkerhoff Jackson J (1994) A sense of place, a sense of time. Yale University Press, New Haven, Connecticut, USA

Brinkman TJ, Chapin T, Kofinas G, Person DK (2009) Linking hunter knowledge with forest change to understand changing deer harvest opportunities in intensively logged landscapes. Ecology and Society 4, 36.

Brook RK, McLachlan SM (2005) On using expert-based science to "test" local ecological knowledge. Ecology and Society 10(2):3-5.

Brook RK, McLachlan SM (2008) Trends and prospects for local knowledge in ecological and conservation research and monitoring. Biodiversity Conservation 17: 3501-3512.

Buxo-Rey MJ (1980) Antropología cognitiva y ecología biocultural: notas sobre el concepto de adaptación. Actas Primer Congreso Español de Antropología (Barcelona) 1:299-318.

Campbell B (1985) Ecología humana. 1 ed. Salvat, Barcelona

Capra F (2004) The hidden connections: a science for sustainable living. Anchor BooksRandom House, New York

Carpenter S, Walker B, Anderies JM, Abel N (2001) From metaphor to measurement: resilience of what to what? Ecosystems 4: 765-781.

Castro FG, Kellison JG, Boyd SJ, Kopak A (2010) A Methodology for conducting integrative mixed methods research and data analyses. Journal of Mixed Methods Research 4: 342-360.
Chesson P (2000) Mechanisms of maintenance of species diversity. Annual Review of Ecology and Systematics 31:343-366.

Clément D (1998) The historical foundations of Etnobiology. Journal of Ethnobiology 18:161187.

Cury A (2013) Armadilhas da mente. Arqueiro, Rio de Janeiro

Danielsen F, Mendoza MM, Tagtag A, Alviola PA, Balete DS, Jensen AE, Enghoff M, Poulsen MK (2007) Increasing conservation management action by involving local people in natural resource monitoring. $A M B I O 36: 566-570$.

Darwin C (1859) On the origin of species by means of natural selection or the preservation of favored races in the struggle for life. John Murray, Londres

Diamond JM (1991) The rise and fall of third chimpanzee. Vintage, London

Diamond JM (2005) Collapsee. Penguin, New York

Diegues AC (2000) Etnoconservação: novos rumos para a proteção da natureza nos trópicos. Hucitec, São Paulo

Diegues AC, Arruda, RSV (2001) Saberes tradicionais e biodiversidade no Brasil. Ministério do Meio Ambiente, Brasília, USP, São Paulo

Dirzo R, Young HS, Galetti M, Ceballos G, Isaac NJB, Collen B (2014) Defaunation in the Anthropocene. Science 345:401-406.

Doughty CE (2013) Preindustrial human impacts on global and regional environment. Annual Review of Environment and Resources 38:503-527.

Drouin JM (1993) L'écologie et son historie. Flamarion, Paris

Dublin HT, Sinclair ARE, McGlade J (1990) Elephants and fire as causes of multiple stable states in the Serengeti-Mara Woodlands. Journal of Animal Ecology 59:1.147-1.164.

Einstein A (1979) Comment j ele monde. Flammarion, Paris

Eisner EW (1990) The meaning of alternative paradigms for practice. In: Guba EG (ed) The paradigm Dialogue. Newbury Park: Sage Publications pp 41-57. 
Ellen R, Parkes P, Bicker A (2000) Indigenous environmental knowledge and its transformations. Harwood Academic Press, Amsterdam

Ellis EC, Ramankutty N (2008) Putting people in the map: anthropogenic biomes of the world. Frontiers in Ecology and the Environment 6:439-447.

Ellis EC, Kaplan JO, Fuller DQ, Vavrus S, Klein Goldewijk K, Verburg PH (2013) Used planet: a global history. Proceedings of the National Academy of Sciences110:7978-7985.

Ellis EC (2015) Ecology in an anthropogenic biosphere. Ecological Monographs 85(3): 287-331.

Elton CS (1927) Animal Ecology, 1st edn, Sidgwick and Jackson, London

Euvé F (2005) Science, foi, sagesse - Fault-il parler de convergence? Les Editions de IÀtelier, Paris

Ferreira-Júnior WS, Ladio AH, Albuquerque UP (2011) Resilience and adaptation in the use of medicinal plants with suspected antiinflammatory activity in the Brazilian Northeast. Journal of Ethnopharmacology 138:238-252.

Ferreira-Júnior WS, Santoro FR, Nascimento ALB, Ladio AH, Albuquerque UP (2013) The role of individuals in the resilience of local medical systems based on the use of medicinal plants-a hypothesis. Ethnobiology and Conservation 2:1-10 doi: http://dx.doi.org/10.15451/ec2013-8-2.1-1-10

Ferreira Júnior WS, Nascimento ALB, Ramos MA, Medeiros PM, Soldati GT, Santoro FR, Reyes-García V, Albuquerque UP (2015) Resilience and adaptation in SocialEcological Systems. In UP Albuquerque, PM Medeiros, Casas A. (eds). Evolutionary Ethnobiology. Springers.

Flos J (2005) El concepto de información en la ecología margalefiana. Ecosistemas, 14 (1): 71.

Folke C (2006) Resilience: the emergence of a perspective for social-ecological systems analysis. Global Environmental Change 16: 253-267.

Forbes $S$ (1887) The lake as a microcosm. Bull. Peoria Science Association: 77-87. Reimp. Illinois Nat. Hist. Surv. Bull. 15: 537-550, 1925. Reimpr. resum. KORMONDY,1965.
Ford RI (1978) The nature and status of ethnobotany. University of Michigan, Anthropological Papers 67.

Ford RI (1994) Ethnobotany: Historical diversity and synthesis. In: Ford RI (Ed.) The nature and status of ethnobotany. University of Michigan, Ann Arbor, pp. 33-49.

Fores M (1983) Science and the Neolithic Paradox, History of Science 21: 141-163.

Foucault M (1995) Crítica e Aufklarung. Tradução de Jorge Dávila. Revista de FilosofiaULA 8.

Garrido-Pérez El, Glasnovic P (2014) The search of human-driven patterns of global plant diversity: why and how? Brenesia 81:96-107

Germano MG, Kulesza WA (2010) Ciência e senso comum: entre rupturas e continuidades. Caderno Brasileiro de Ensino de Física (Online) 27: 123-135. doi: 10.5007/21757941.2010v27n1p115

Germano MG (2011) Uma nova ciência para um novo senso comum. 1. ed. EDUEPB, Campina Grande

Goerner SJ (1994) Chaos and the evolving ecological universe. Gordon \& Breach Publishing, Langhorne Pennsylvania

Graham MH, Dayton PK (2002) On the Evolution of Ecological Ideas: Paradigms and Scientific Progress. Ecology 83: 1481-1489.

Grmek MD (1997) Le legs de Claude Bernard. Fayard, Paris

Groot RS, Alkemade R, Braat L, Hein L, Willemen $L$ (2010) Challenges in integrating the concept of ecosystem services and values in landscape planning, management and decision making. Ecological Complexity 7: 260-272.

Guerra Sierra A, del Hierro SP (2008) La descomposición de la ecología. Netbiblo, Oleiros.

Gunderson LH (2000) Ecological resilience - In theory and application. Annual Review of Ecology and Systematics 31: 425-439.

Haeckel E (1866) Generelle Morphologie der Organismen: Algmeine Grundzuge der organischen Formen-Wissenschaft, mecanisch begrundet durch die von Charles Darwin reformiste Descendenz-Theorie. 2 vols. Georg Reimer, Berlim 
Hardesty D (1979) Antropología ecológica. 1 ed. Bellaterra, Barcelona

Helfman GS (2007) Fish Conservation: a guide to understanding and restoring global aquatic biodiversity and fishery resources, first ed., Island Press, Washington D.C

Holck MH (2008) Participatory forest monitoring: an assessment of the accuracy of simple cost-effective methods. Biodiversity and Conservation 17: 2023-2036.

Holling CS (1973) Resilience and stability of ecological systems. Annual Review of Ecology and Systematics 4: 1-23.

Hunn E (2007) Ethnobiology in four phases. Journal of Ethnobiology 27(1): 1-10

Huntington HP (2000) Using traditional ecological knowledge in science: methods and applications. Ecological Applications 10:1270-1274.

Huntington HP (2011) The local perspective. Nature 478: 182-183.

Huntington HP, Suydam RS, Rosenberg DH (2004) Traditional knowledge and satellite tracking as complementary approaches to ecological understanding. Environmental Conservation 31(3):177-180.

Hurrell JA (1987) Las posibilidades de la etnobotánica y un nuevo enfoque a partir de la ecología y su propuesta cibernética. Revista Española de Antropología Americana (Madrid) 17:235-257.

Hurrell JA (1990) Interpretación de relaciones en ecología a partir de la noción de sistema. Tesis Doctoral Nro. 548. Facultad de Ciencias Naturales y Museo. Universidad Nacional de La Plata. Argentina

Hurrell JA (2014) Urban Ethnobotany in Argentina: Theoretical advances and methodological strategies. Ethnobiology and Conservation 3(2):1-11.

Hurrell JA, Albuquerque, UP (2012) Is Ethnobotany an Ecological Science? Steps towards a complex Ethnobotany. Ethnobiology and Conservation 1: 1-10.

Jones NA, Ross H, Lynam T, Perez P, Leitch A (2011) Mental models: an interdisciplinar synthesis of theory and methods. Ecology and Society 16(1): 46.
Kant I (1966) Réflexions sur I education. Trad. Aléxis Philonenko. J. Vrin, Paris

Kormondy EJ (1969) Concepts of ecology. Prentice-Hall, Englewood Cliffs

Krausmann F, Erb KH, Gingrich S, Haberl H, Bondeau A, Gaube V, Lauk C, Plutzar C, Searchinger TD (2013) Global human appropriation of net primary production doubled in the 20th century. Proceedings of the National Academy of Sciences USA 110:10324-10329.

Krebs CJ, Boonstra R, Boutin S, Sinclair ARE (2001) What drives the 10-years cycle of snowshoe hares? BioScience 51(1):25-35.

Kuhn T (1962) The structure of scientific revolutions. University of Chicago Press, Chicago

Lamarck JB (1809) Philosophie Zoologique. Disponível em [http://www.lamarck.cnrs.fr/] Accessed 19 April 2017

Leff E (2002) Epistemologia Ambiental. 3a ed., Cortez, São Paulo

Lévi-Strauss C (1964) Mythologiques. v.1: "Le cru et le cuit", Plon, Paris

Losos JB, Schluter D (2000) Analysis of an evolutionary species-area relationship. Nature 408 (6814):847- 850.

Lotka AJ (1925) Elements of Physical Biology. Baltimore (MD): Williams and Wilkins.

MacArthur, R.H. and Pianka, E.R. (1966) On optimal use of a patchy environment. American Naturalist 100 (916): 603-609.

Marques JGW (2001) Pescando pescadores: ciência e etnociência em uma perspectiva ecológica. NUPAUB, São Paulo

Martin JF (1983) Optimal foraging theory: a review of some models and their applications. American Anthropologist 85: 612-629.

Maturana H, Varela F (1972) De máquinas y seres vivos. 1 ed. Editorial Universitaria, Santiago de Chile

Maturana H (1977) A ontologia da realidade. Mago C, Graciano M, Vaz N (org). Ed. UFMG, Belo Horizonte

Maturana H (2007) Transformación en la convivencia. 1 ed. Lom Ediciones, Santiago de Chile 
May R (1989) The chaotic rhythms of life. New Scientist 18:37-41.

McCune, B, Allen THE (1985) Will similar forests develop on similar sites? Canadian Journal of Botany 63:367-376.

Mclntosh RP (1985) The background of ecology: concept and theory. Cambridge University Press, Cambridge, UK

McIntosh RP (1987) Pluralism in ecology: concept and theory. Annual Review of Ecology System 18: 321-341.

Minayo MCS, Sanches O (1993) Quantitativoqualitativo: oposição ou complementaridade? Caderno Saúde Pública 9: 237-248.

Minayo MCS (2003) Ciência, técnica e arte: o desafio da pesquisa social. In Minayo MSC (org.) Pesquisa Social: Teoria, Método e Criatividade. $22^{\mathrm{a}}$ ed., Vozes, Petrópolis, pp 929.

Mittermeier R et al (2003) Wilderness and biodiversity conservation. PNAS 100(18):10309-10313.

Morin E (1973) Le paradigme perdu: la nature humaine. 1 ed. Seuil, Paris

Morin E (1980) Le Méthode II. Lavie de la vie. 1 ed. Seuil, Paris

Morin E (1985) O Problema Epistemológico da Complexidade. 1 ed. Publ. Europa-America, Lisboa

Morin E (1990) Introduction à la pensée complexe. 1 ed. ESF Editeur, Paris

Morin E (1999) Complexidade e transdisciplinaridade. A reforma da universidade $e$ do ensino fundamental. Tradução Edgard de Assis Carvalho. UFRN, Natal

Morin E, Le Moigne JL (2000) A inteligência da complexidade. Tradução Nurimar Maria Falci. São Paulo: Peirópolis

Nabhan GP (2001) Cultural perceptions of ecological interactions-an endangered peoples contribution to the conservation of biological and linguistic diversity. In: Maffi L (ed) On Biocultural Diversity: linking language, knowledge and the environment. Smithsonian Institute Press, Washington, DC, pp 145-156.

Nabhan GP (2009) Ethnoecology: bridging disciplines, cultures and species. Journal of Ethnobiology 29: 3-7.
Naess Arne (1973) The Shallow and the Deep, Long-Range Ecology Movement: A Summary. Inquiry: An Interdisciplinary Journal of Philosophy and the Social Sciences 16: 95-100.

Naess Arne (1984) Intuition, Intrinsic Value and Deep Ecology. The Ecologist 14(5,6): 201-203.

Nascimento AL, Ferreira Júnior W.S, Ramos MA, Medeiros PM, Soldati GT, Santoro FR, Albuquerque UP (2015) Utilitarian Redundancy: Conceptualization and Potential Applications in Ethnobiological Research. In: Albuquerque UP, Medeiros PM, Casas A (2015a) Evolutionary Ethnobiology. Springer Cham Heidelberg, New York Dordrecht London, p.121130.

Neves W (2002) Antropologia Ecológica: um olhar materialista sobre as sociedades humanas. $2^{\mathrm{a}}$ Ed. Cortez, São Paulo

Nietzsche F (2001) A gaia ciência. Tradução de Paulo de Souza. Companhia das Letras, São Paulo

Odum EP (1977) The emergence of ecology as a new integrative discipline. Science 195 (4284): 1289-1293.

Peroni N, Hanazaki N, Araujo H (2010) Métodos ecológicos na investigação etnobotânica e etnobiológica: 0 uso de medidas de diversidade e estimadores de riqueza. In: Albuquerque UP, Lucena RFP, Cunha LVFC (2010). Métodos e técnicas na pesquisa etnobiológica e etnoecológica. NUPEEA, Recife, pp. 255-276.

Perry G, Pianka ER (1997) Animal foraging: past, present and future. Trends in Ecology \& Evolution 12 (9): 360-364.

Pickett S, Parker V, Fiedler P (1991) The new paradigm in ecology. In Fiedler $P$, Jain $S$ (eds) Conservation Biology. Chapman and Hall, New York, pp 65-88.

Pierotti R, Wildcat D (2000) Traditional ecological knowledge: the third alternative. Ecological Applications 10(5):1333-1340.

Pimentel DU, Stachow DA, Takacs RW, Brubaker AR, Dumas JJ, Meaney JAS, O'Neil DE, Onsi, DB Corzilius (1992) Conserving biological diversity in agricultural/forestry systems. BioScience 42: 354-362.

Pimm SL, Jenkins CN, R. Abell TM, Brooks JL, Gittleman LN, Joppa PH, Raven CM, Roberts JO, Sexton (2014) The biodiversity of species and their rates of extinction, distribution, and protection. Science 344:6187. 
Popper K (1959) The Logic of Scientific Discovery. Basic Books, New York, NY

Posey DA (1987) Etnobiologia: teoria e prática. In Ribeiro B (ed.) Suma etnológica brasileira - 1 Etnobiologia. Petrópolis, Vozes/Finep. pp. 15-21.

Prigogine I (1994) Temps à devenir. À propôs de lorigine du temps. Museé de la civilisation/Fides, Quebec

Prigogine I (2001) Ciência, razão e paixão. Almeida MC, Carvalho EA (Org), EDUEPA. Belém

Pyke GH (1984) Optimal foraging theory: a critical review. Annual Review of Ecology and Systematics 15: 523-575.

Reice SR (1994) Nonequilibrium determinants of biological community structure. American Scientist 82(5):424-435

Reldman ChL, Kinzig AP (2003) Resilience of past landscapes: resilience, theory, society, and the Longue Dureé. Conservation Ecology 7(1):14-40.

Reyes-Garcia V, Sanz MN (2007) Etnoecologia: punto de encuentro entre natureleza $y$ cultura. Ecossistemas 16: 46-55.

Reyes-García V, Kightley E, Ruiz-Mallén I, Fuentes-Pelaez N, Demps $\mathrm{K}$, Huanca $\mathrm{T}$, Martínez-Rodríguez MR (2010) Schooling and local ecological knowledge: Do they complement or substitute each other? International Journal of Educational Development 30:305-313.

Rozzi R (1999) The Reciprocal Links between Evolutionary-Ecological Sciences and Environmental Ethics. Bioscience 49:911-921.

Rudlle K (1993) The transmission of traditional ecological knowledge. In: Traditional Ecological Knowledge: concepts and cases. Ottawa, IDRC. pp. 17-31.

Ruddle K (1994) Local knowledge in the folk management of fisheries and coastal marine environments In: Dyer CL, McGoodwin JR (Eds.). Folk Management in the World's Fisheries. University Press of Colorado, Niwot, Colorado, pp. 161-206.

Sanchez-Azofeifa, GA, Kalacska M, Quesada M, Calvo-Alvarado JC, Nassar JM, Rodríguez JP (2005) Need for integrated research for a sustainable future in tropical dry forests. Conservation Biology 19:285-286.
Schrodinger E (1997) O princípio da objetivação. In: $O$ que é a vida? $O$ aspecto físico da celula viva. Mente e matéria e fragmentos autobiográficos. Fundação Editora da UNESP, São Paulo

Scudo FM, Ziegler JR (1978) The Golden age of theoretical ecology. 1923-1940. Springer Verlag, Berlin

Sih A, Christensen B (2001) Optimal diet theory: when does it work, and when and why does it fail? Animal Behaviour 61(2): pp.379390

Stepp JR (2005) Advances in Ethnobiological. Fild Methods 17: 211-218.

Sturtevant WC (1964) Studies in ethnoscience. American Anthropologist 66(3): 99-131.

Tansley AG (1914) Presidential address. Journal of Ecology 2:194-202.

Thienemann A (1926) Limnologie. Jedermanns B, cherei, Breslau

Tilman D (1986) Evolution and differentiation in terrestrial plant communities: the importance of the soil resource: light gradient. In: Diamond J, Case TJ (Eds) Community ecology. Harper and Row, New York, p.359-380.

Toledo VM (1992) What is ethnoecology? Origins, scope and implications of a rising discipline. Etnoecologicá 1:5-21.

Toledo VM (2001) Indigenous people and Biodiversity. Encyclopedia of Biodiversity 3: 451-463.

Toledo VM (2002) Ethnoecology: a conceptual framework for the study of indigenous knowledge of nature. In: Stepp JR et al. (eds.). Ethnobiology and biocultural diversity. Atlanta: International Society of Ethnobiology, p. 511-522.

Toledo V, Barrera-Bassols N (2008) La memoria biocultural: la importância ecológica de las sabidurias tradicionales. Icaria editorial, Barcelona

Toledo V, Barrera-Bassols N (2010) A etnoecologia: uma cência pós-normal que estuda as sabedorias tradicionais. In: Silva VA, Almeida ALS, Albuqueruqe UP (orgs) Etnobiologia e Etnoecologia: pessoas e natureza na Ámerica Latina. Recife: NUPPEA. pp. 13 36. 
Turvey ST, Fernández-Secades C, Nuñez-Miño JM, Hart T, Martinez P, Brocca JL, Young RP (2014) Is local ecological knowledge a useful conservation tool for small mammals in a Caribbean multicultural landscape? Biological Conservation 169:189-197.

Vandebroek I, Reyes-García V, Albuquerque UP, Bussmann R, Pieroni A (2011) Local Knowledge: Who cares? Journal of Ethnobiology and Ethnomedicine 7(35): 2-7.

Walker BH (1992) Biodiversity and ecological redundancy. Conservation Biology 6:18-23.

Walker B, Holling CS, Carpenter SR, Kinzig A (2004) Resilience, adaptability and transformability in social-ecological systems. Ecological and Society 9(2):5-12.

Wellnitz T, Poff NL (2001) Functional redundancy in heterogeneous environments: implications for conservation. Ecology Letter 4:177-179.
Wells MP, Mcshane TO (2004) Integrating protected area management with local needs and aspirations. Ambio 33: 513-519.

West PC, Igoe J, Brockingto, D (2006) Parks and people: the social impact of protected areas. Annual Review of Anthropology 35: 251-277.

Wimsatt WC (1982) Reductionistic research strategies and their biases in the units of selection controversy. In: Saarinen $E$ (ed.) Conceptual issues in ecology, D. Reidel, Dordrecht, pp. 155- 201.

Whittaker RJ, Fernandez-Palacios JM (2007) Island Biogeography: Ecology, Evolution and Conservation. Second Edition. University Press, Oxford (UK): Oxford
Received: 22 April 2017

Accepted: 13 August 2017

Published: 18 August 2017 